\title{
Physical activity of children with Down syndrome - preliminary validation of a questionnaire
}

\section{Aktywność fizyczna dzieci z zespołem Downa - wstępna walidacja kwestionariusza}

\author{
Anna Wrzochal' ${ }^{1}$ Edyta Suliga ${ }^{2}$ \\ ${ }^{1}$ Collegium Medicum, Jan Kochanowski University, Kielce, Poland \\ Head of the Collegium: Prof. Marianna Janion MD, PhD \\ 2Department of Nutrition and Dietetics, Institute of Health Sciences, Collegium Medicum, Jan Kochanowski University, Kielce, Poland \\ Head of the Department: Prof. JKU Edyta Suliga
}

Key words: reproducibility, validation, physical activity questionnaire, children with Down syndrome.

Słowa kluczowe: powtarzalność, walidacja, kwestionariusz aktywności fizycznej, dzieci z zespołem Downa.

\begin{abstract}
Introduction: Regular physical activity and compliance with the guidelines for using electronic devices have an important impact on health and quality of life as well as the healthy development of children and adolescents.

Aim of the research: To validate the author's questionnaire used to assess physical activity of children aged 5-14 as well as to compare the level of physical activity of children with Down syndrome (DS) with their peers without this syndrome. Material and methods: A survey was conducted among 48 parents of children with DS and 55 parents of children without DS. The questionnaire was validated by determining its repeatability and determining the values of the $\kappa$ coefficient. The comparison of the level of physical activity was made using the Pearson's $\chi^{2}$ test.

Results: The comparison of the results obtained in the first and second study did not show significant differences in children with DS and without DS. The results obtained in both studies $(\kappa \geq 0.81)$ were consistent. It was found that children with DS spent significantly less time on physical education classes and team games, while spending significantly more time on doing gymnastics $(p<0.05)$

Conclusions: The author's questionnaire can be considered an accurate measurement tool that can be used both to test the level of physical activity of children with DS and children without genetic disorders. More children without DS than children with DS (76\% vs. $60 \%)$ comply with the recommendations for moderate and intense physical activity. Significant differences were also noted in relation to the time allocated to particular forms of physical activity.
\end{abstract}

\section{Streszczenie}

Wprowadzenie: Regularna aktywność fizyczna i przestrzeganie zasad korzystania z urządzeń elektronicznych mają szczególny wpływ na zdrowie i jakość życia oraz prawidłowy rozwój dzieci i młodzieży.

Cel pracy: Walidacja autorskiego kwestionariusza służącego do oceny aktywności fizycznej dzieci w wieku 5-14 lat oraz porównanie poziomu aktywności fizycznej dzieci z zespołem Downa (ZD) z aktywnością ich rówieśników bez zespołu.

Materiał i metody: Przeprowadzono badanie ankietowe wśród 48 rodziców dzieci z ZD oraz 55 rodziców dzieci bez zespołu. Walidacji kwestionariusza dokonano poprzez określenie jego powtarzalności, wyznaczając wartości współczynnika $\kappa$. Porównanie poziomu aktywności fizycznej przeprowadzono za pomocą testu $\chi^{2}$ Pearsona.

Wyniki: Porównanie wyników uzyskanych w pierwszym i drugim badaniu nie wykazało istotnych różnic zarówno u dzieci z ZD, jak i bez zespołu. Dla wszystkich pytań stwierdzono bardzo dobrą zgodność pomiędzy wynikami uzyskanymi w obu badaniach $(\kappa \geq 0,81)$. Stwierdzono, że dzieci z ZD spędzały istotnie mniej czasu na zajęciach wychowania fizycznego oraz na grach zespołowych, natomiast istotnie więcej czasu na gimnastyce $(p<0,05)$.

Wnioski: Opracowany kwestionariusz można uznać za trafne narzędzie pomiarowe, które może być wykorzystywane zarówno do badania poziomu aktywności fizycznej dzieci z ZD, jak i dzieci bez chorób genetycznych. Zalecenia dotyczące czasu umiarkowanej i intensywnej aktywności spełniało więcej dzieci bez ZD niż dzieci z ZD (76\% vs 60\%). Znaczące różnice odnotowano także w przypadku czasu przeznaczanego na poszczególne formy aktywności fizycznej. 


\section{Introduction}

Regular physical activity, a good night's rest and compliance with the guidelines for the use of electronic devices have an important impact on health and quality of life, as well as on the healthy development of children and adolescents [1-3]. Physical activity ensures a good physical and mental condition, improves bone mineralization and increases the amount of muscle tissue while reducing the amount of fat, thereby reducing the risk of developing many lifestyle diseases. These include overweight and obesity, which are an increasingly serious problem in the modern world affecting an increasing number of ever younger people. It affects the maintenance of appropriate levels of cholesterol, triglycerides and blood glucose [1, 4]. It also helps to relieve the emotional tension associated with high levels of stress to which the youth is exposed [4].

Physical activity is the base of the healthy eating pyramid and the healthy lifestyle guidelines for children and youth. According to the recommendations of the Institute of Food and Nutrition, children and adolescents should be physically active for at least an hour a day, at the same time limiting screen time (this includes watching TV, using a computer and other electronic devices) to $2 \mathrm{~h}$ a day [5].

In recent years, leisure activities have changed. The development of technology (computers, mobile phones, game consoles, etc.) has significantly influenced the way children spend their free time and their level of physical activity. Movement in the fresh air or playing with peers were replaced by using the above-mentioned devices and spending free time in a sitting position $[6,7]$.

Metabolic disorders, abnormal blood leptin levels and comorbidities such as hypothyroidism are among the causes of overweight and obesity in children with Down syndrome (DS) [8-10]. However, it is worth paying attention not only to genetic conditions, but also to social background, poor eating habits and insufficient levels of physical activity of children with DS [8]. The low level of physical activity in children with DS may be associated with their low physical performance, resulting from the accompanying defects of the musculoskeletal system and muscular and osteoarticular disorders [11]. Aversion to physical activity and social stigmatization have also been observed. Physical activity in children with DS plays a special role. These children often require specialist care and physiotherapy. Physical activity may support their development, improve mobility and play a therapeutic role [12].

Due to the significant impact of physical activity on the health and development of children and adolescents, it is important to use standardized methods of its assessment, which would give one the possibility to monitor activity, compare the results of research conducted nationally and globally, and assess the effectiveness of intervention programs. Among the methods of assessing human motor activity, we can distinguish objective and subjective methods [13]. Objective methods using motion sensors, e.g. pedometers, are preferred in research. However, due to the high cost, they are not widely used in research. The available motion sensors also have their limitations the inability to measure some types of activities, e.g. water sports, cycling, and activities that require primarily upper body movements. On the other hand, subjective methods allow for a comprehensive assessment of physical activity related to all aspects of life, and at the same time they do not require complicated and expensive equipment and are not burdensome for the participants of the research.

To the best of our knowledge, there are few surveys used to test the physical activity of children and adolescents, especially those that would also be verified among children with genetic diseases or other developmental disorders.

\section{Aim of the research}

The aim of the study was to validate the author's questionnaire used to assess the physical activity of children aged 5-14 by determining its repeatability among children with DS and children without DS. In addition, the purpose of the research was to compare the level of physical activity of children with DS to the activity of their peers without the syndrome.

\section{Material and methods}

\section{Organization of research and sample selection}

The research was conducted from October to December 2019 among parents of children with DS and those without the syndrome living in Poland. The sample was collected using snowball sampling among parents belonging to associations and foundations to which children and parents of children with DS belong, as well as in kindergartens and primary schools which the children attend. The survey was conducted in the form of an online questionnaire using a free Google form. In order to pair the results of surveys completed 2 weeks apart, in addition to the child's data (age, sex), they were asked to code the survey by additionally entering the date of birth of the parent completing the survey.

The study involved 57 parents of children with DS and 58 parents of children without DS. The collected data were verified and organized by removing questionnaires that were completed only once. In the process of verification, 9 surveys completed by parents of children with DS and 3 surveys completed by parents of children without DS were excluded. The questionnaire was completed twice by 48 parents of children with DS and 55 parents of children without 
DS. Among the children with DS, there were 28 girls and 20 boys, while in the group without DS, there were 30 girls and 25 boys. The study was conducted among children aged 5-14. In children with DS, the average age was $9.25 \pm 2.82$ years, while in children without DS it was $9.91 \pm 2.75$ years.

The research was conducted with the consent of the Bioethical Committee operating at the Collegium Medicum of the Jan Kochanowski University, Poland.

\section{Questionnaire characteristics}

The questionnaire used to assess the level of physical activity of children aged 5-14 contains 13 questions regarding various forms of physical activity on weekdays and at weekends. The questions regarded, among others, the number of hours of physical education classes at school or the number of hours of physical activities in kindergarten. In subsequent questions, the parent was to determine whether the child is physically active outside of physical education classes and indicate the forms of these activities (walking, cycling, team games, running, swimming, gymnastics, dancing, playground or other) as well as providing the average time of physical activity per week. The next part of the survey included questions about the time of doing housework and walking, as well as the time spent in front of the TV and computer and doing homework, reading and playing in a sitting position. The parent was to indicate the answers broken down into performing activities on weekdays and at weekends. Answers to these questions ranged from 0 to 6 and more hours on weekdays or at weekends. In addition, the questionnaire included questions about the child's data, such as sex and age.

Validation of the questionnaire by determining its repeatability was done by comparing the results of the physical activity evaluation obtained with the validated method with the results obtained with the same method that was repeated (comparison: 'test-retest'), assuming that the test and re-test measurement conditions are the same.

Validation and comparison of physical activities of different intensities were made by grouping individual activities into moderate-to-vigorous physical activities (MVPA), light physical activities (LPA) and sitting time. MVPA included physical education classes and additional physical activities. Housework and walking were assigned to LPA. Watching television, sitting in front of a computer, playing and doing homework seated qualified for activities performed in a sitting position.

\section{Statistical analysis}

Statistical analysis was performed using the PQStat program and Excel. Feature values were expressed using arithmetic means $(x)$ and standard deviations (SD).
The repeatability of the questionnaire was checked by determining the kappa coefficient ( $\kappa$ ) between the results obtained for the same people in the first and second study, thus determining intra-individual variability. Inter-individual variability was analyzed by comparing physical activity using Pearson's $\chi^{2}$ test. The analyses were carried out separately for children with and without DS. The comparison of the level of physical activity of children with and without DS was made using Pearson's $\chi^{2}$ test, analyzing the answers from the first interview. A significance level of $p<0.05$ was adopted.

\section{Results}

Comparison of the results obtained in the first and second studies, which took place 2 weeks apart, did not show significant differences in either children with DS (Table 1) or those without DS (Table 2). The results obtained in both studies were highly consistent $(\kappa \geq 0.81)$.

In children with DS, the repeatability of results was the highest for weekend housework $(\kappa=1.00)$ and lowest for time spent on the playground in the question about additional physical activities and for walking on weekdays $(\kappa=0.84)$ (Table 1$)$. In children without DS, the highest repetition was observed for additional physical activities such as running, swimming/swimming classes and dancing $(\kappa=1.00)$. On the other hand, the lowest repeatability was obtained for walking on weekdays $(\kappa=0.81)$ (Table 2$)$.

An analysis was also made of the results obtained in the first and second studies, broken down into physical activity of varying intensity. Comparison of the results for both children with DS (Table 3) and children without DS (Table 4) showed no significant differences. For all intensities of physical activities, high consistency was found between the results obtained in both studies $(\kappa \geq 0.81)$. In children with DS, the repeatability of results was highest for low-intensity physical activity $(\kappa=0.94)$ and lowest for time spent in a sitting position $(\kappa=0.90)$ (Table 3$)$. In children without DS, the highest repeatability was obtained in the case of moderate or high intensity activities $(\kappa=0.95)$, and the lowest for time spent in a sitting position $(\kappa=0.89)$ (Table 4$)$.

When assessing the physical activity of children with DS against their peers without DS, the results of the first study were compared. Table 5 summarizes the detailed results of individual activities, broken down into weekdays and weekends. Statistically significant differences were obtained in the case of physical education classes and additional physical activities, such as team games and gymnastics $(p<0.05)$. Children with DS spent significantly less time on physical education classes and team games. However, it was found that children with DS spent significantly more time on gymnastics compared to children without DS. 
Table 1. Comparison of the results of the $1^{\text {st }}$ and $2^{\text {nd }}$ study of physical activity of children with Down syndrome broken down into physical activity on weekdays and at weekends. Validation phase (h/day)

\begin{tabular}{|c|c|c|c|c|}
\hline Variables & $\begin{array}{c}1^{\text {st }} \text { study } \\
x \pm S D \\
{[\text { h/day }]}\end{array}$ & $\begin{array}{c}2^{\text {nd }} \text { study } \\
x \pm \text { SD } \\
{[\text { h/day }]}\end{array}$ & $\begin{array}{c}\text { Pearson's } \chi^{2} \\
\text { test's level } \\
\text { of significance }\end{array}$ & $\begin{array}{l}\text { Kappa }(\kappa) \\
\text { coefficient }\end{array}$ \\
\hline \multicolumn{5}{|l|}{ Physical activity on weekdays: } \\
\hline PE classes & $0.27 \pm 0.14$ & $0.27 \pm 0.15$ & NS & $0.94^{\star}$ \\
\hline Additional physical activities: & $0.88 \pm 1.08$ & $0.88 \pm 1.07$ & & 0.91 \\
\hline Going for walks & $0.26 \pm 0.21$ & $0.27 \pm 0.21$ & NS & $0.94^{\star}$ \\
\hline Cycling & $0.04 \pm 0.08$ & $0.03 \pm 0.07$ & NS & $0.94^{\star}$ \\
\hline Team games & $0.04 \pm 0.09$ & $0.05 \pm 0.10$ & NS & $0.90^{*}$ \\
\hline Running & $0.05 \pm 0.09$ & $0.04 \pm 0.08$ & NS & $0.85^{\star}$ \\
\hline Swimming/swimming classes & $0.07 \pm 0.11$ & $0.06 \pm 0.09$ & NS & $0.92^{*}$ \\
\hline Gymnastics & $0.21 \pm 0.20$ & $0.21 \pm 0.20$ & NS & $0.97^{\star}$ \\
\hline Dance & $0.04 \pm 0.08$ & $0.05 \pm 0.09$ & NS & $0.95^{\star}$ \\
\hline Playground & $0.07 \pm 0.11$ & $0.08 \pm 0.11$ & NS & $0.84^{*}$ \\
\hline Others & $0.09 \pm 0.13$ & $0.08 \pm 0.13$ & NS & $0.85^{\star}$ \\
\hline Housework & $0.28 \pm 0.18$ & $0.27 \pm 0.18$ & NS & $0.97^{\star}$ \\
\hline Movement (on foot) & $1.13 \pm 0.76$ & $1.17 \pm 0.75$ & NS & $0.84^{\star}$ \\
\hline Watching TV & $1.96 \pm 1.22$ & $1.96 \pm 1.24$ & NS & $0.95^{\star}$ \\
\hline Sitting in front of the computer & $1.23 \pm 1.21$ & $1.23 \pm 1.19$ & NS & $0.94^{\star}$ \\
\hline Playing and doing homework in a sitting position & $2.92 \pm 1.56$ & $2.83 \pm 1.62$ & NS & $0.85^{\star}$ \\
\hline \multicolumn{5}{|l|}{ Physical activity at the weekend: } \\
\hline Housework & $0.54 \pm 0.49$ & $0.54 \pm 0.49$ & NS & $1.00^{\star}$ \\
\hline Movement (on foot) & $1.21 \pm 0.99$ & $1.25 \pm 1.02$ & NS & $0.94^{\star}$ \\
\hline Watching TV & $1.83 \pm 1.06$ & $1.83 \pm 1.04$ & NS & $0.89^{*}$ \\
\hline Sitting in front of the computer & $1.06 \pm 1.08$ & $1.10 \pm 1.04$ & NS & $0.88^{*}$ \\
\hline Playing and doing homework in a sitting position & $2.42 \pm 1.29$ & $2.42 \pm 1.29$ & NS & $0.89^{*}$ \\
\hline
\end{tabular}

$x \pm S D-$ mean \pm standard deviation, NS - non-significant, ${ }^{*} \kappa$ coefficient's significance level $(p<0.05)$.

Physical activities of varying intensity in children with and without DS were also compared (Table 6). The answers obtained indicate that children with DS had a lower level of average physical activities of moderate or high intensity compared to children without DS. In the first group, the average duration of these activities was $1.15 \mathrm{~h} /$ day, while in the second group it was found to be $1.33 \mathrm{~h} /$ day. The average duration of low-intensity physical activity in children with DS was also lower $(1.50 \mathrm{~h} /$ day $)$ than in children without DS (1.77 h/day). Sitting time in children with DS and children without DS was similar. Children with DS spent an average of $5.88 \mathrm{~h} /$ day in a seated position, while children without DS spent $6.18 \mathrm{~h}$ /day in a seated position. Importantly, this time did not include, among older children, the time spent seated during school lessons. However, none of the analyzed differences reached the level of statistical significance.

\section{Discussion}

The validation of the questionnaire showed no significant differences between the results of both studies, which indicates low intra-individual variability and high repeatability of the results obtained. The range of obtained values of $\kappa$ coefficients was 0.81-1.00, which shows a high consistency between the results obtained in both studies. Validation of physical activity questionnaires carried out by other authors was associated with significantly lower $\kappa$ values, which indicated moderate or low consistency of the results of the questionnaires [14-17]. Considering the huge need to conduct research on the impact of physical activity and sedentary behavior of children on the risk of adverse health effects in later life, the developed questionnaire will be a useful tool. 
Table 2. Comparison of the results of the $1^{\text {st }}$ and $2^{\text {nd }}$ study of physical activity of children without Down syndrome broken down into physical activity on weekdays and at weekends. Validation phase (h/day)

\begin{tabular}{|c|c|c|c|c|}
\hline Variables & $\begin{array}{c}1^{\text {st }} \text { study } \\
x \pm S D \\
{[\text { h/day }]}\end{array}$ & $\begin{array}{c}2^{\text {nd }} \text { study } \\
x \pm S D \\
{[h / \text { day }]}\end{array}$ & $\begin{array}{c}\text { Pearson's } \chi^{2} \\
\text { test's level } \\
\text { of significance }\end{array}$ & $\begin{array}{l}\text { Kappa (к) } \\
\text { coefficient }\end{array}$ \\
\hline \multicolumn{5}{|l|}{ Physical activity on weekdays: } \\
\hline PE classes & $0.40 \pm 0.15$ & $0.40 \pm 0.15$ & NS & $0.95^{*}$ \\
\hline Additional physical activities & $0.93 \pm 1.19$ & $0.95 \pm 1.19$ & & 0.95 \\
\hline Going for walks & $0.31 \pm 0.20$ & $0.32 \pm 0.21$ & NS & $0.88^{*}$ \\
\hline Cycling & $0.06 \pm 0.10$ & $0.07 \pm 0.11$ & NS & $0.96^{\star}$ \\
\hline Team games & $0.09 \pm 0.12$ & $0.09 \pm 0.13$ & NS & $0.97^{\star}$ \\
\hline Running & $0.08 \pm 0.13$ & $0.08 \pm 0.13$ & NS & $1.00^{\star}$ \\
\hline Swimming/swimming classes & $0.06 \pm 0.10$ & $0.06 \pm 0.10$ & NS & $1.00^{\star}$ \\
\hline Gymnastics & $0.07 \pm 0.13$ & $0.07 \pm 0.12$ & NS & $0.96^{*}$ \\
\hline Dance & $0.06 \pm 0.13$ & $0.06 \pm 0.13$ & NS & $1.00^{\star}$ \\
\hline Playground & $0.10 \pm 0.15$ & $0.10 \pm 0.14$ & NS & $0.88^{*}$ \\
\hline Others & $0.09 \pm 0.12$ & $0.09 \pm 0.13$ & NS & $0.94^{\star}$ \\
\hline Housework & $0.29 \pm 0.21$ & $0.28 \pm 0.21$ & NS & $0.98^{\star}$ \\
\hline Movement (on foot) & $1.42 \pm 0.90$ & $1.38 \pm 0.95$ & NS & $0.81^{*}$ \\
\hline Watching TV & $1.96 \pm 1.14$ & $1.92 \pm 1.15$ & NS & $0.95^{*}$ \\
\hline Sitting in front of the computer & $1.35 \pm 1.04$ & $1.27 \pm 0.97$ & NS & $0.90^{*}$ \\
\hline Playing and doing homework in a sitting position & $3.00 \pm 1.51$ & $2.98 \pm 1.68$ & NS & $0.86^{\star}$ \\
\hline \multicolumn{5}{|l|}{ Physical activity at the weekend: } \\
\hline Housework & $0.69 \pm 0.37$ & $0.68 \pm 0.38$ & NS & $0.97^{\star}$ \\
\hline Movement (on foot) & $1.25 \pm 0.78$ & $1.25 \pm 0.80$ & NS & $0.88^{*}$ \\
\hline Watching TV & $2.09 \pm 1.51$ & $2.09 \pm 1.54$ & NS & $0.91^{*}$ \\
\hline Sitting in front of the computer & $1.31 \pm 1.22$ & $1.18 \pm 1.00$ & NS & $0.85^{\star}$ \\
\hline Playing and doing homework in a sitting position & $2.44 \pm 1.20$ & $2.45 \pm 1.23$ & NS & $0.88^{\star}$ \\
\hline
\end{tabular}

$x \pm S D-$ mean \pm standard deviation, NS - non-significant, ${ }^{*} \kappa$ coefficient's significance level $(p<0.05)$.

Table 3. Comparison of the results of $1^{\text {st }}$ and $2^{\text {nd }}$ study of physical activity of children with Down syndrome broken down into physical activity of varying intensity. Validation phase (h/day)

\begin{tabular}{|c|c|c|c|c|}
\hline Intensity of physical activity & $\begin{array}{c}1^{\text {st }} \text { study } x \pm S D \\
{[\text { h/day }]}\end{array}$ & $\begin{array}{c}2^{\text {nd }} \text { study } x \pm S D \\
{[\text { h/day }]}\end{array}$ & $\begin{array}{c}\text { Pearson's } \chi^{2} \\
\text { test's level } \\
\text { of significance }\end{array}$ & $\begin{array}{l}\text { Kappa (к) } \\
\text { coefficient }\end{array}$ \\
\hline $\begin{array}{l}\text { Moderate-to-vigorous physical activity } \\
\text { (MVPA) }\end{array}$ & $1.15 \pm 1.22$ & $1.15 \pm 1.22$ & NS & $0.93^{*}$ \\
\hline Light physical activity (LPA) & $1.50 \pm 1.10$ & $1.54 \pm 1.10$ & NS & $0.94^{*}$ \\
\hline Sitting time & $5.88 \pm 3.83$ & $5.83 \pm 3.86$ & NS & $0.90^{\star}$ \\
\hline
\end{tabular}

$x \pm S D-$ mean \pm standard deviation, $N S-$ non-significant, ${ }^{*} \kappa$ coefficient's significance level $(p<0.05)$.

Analysis of the results showed that both children with and without DS, at the age of 5 to 14 , were physically active - they spent quite a lot of time on moderate or intense physical activities. The average time of these activities in both groups exceeded the recom- mended physical activity - 60 min per day. However, this recommendation was fulfilled by significantly more children without DS (76\%) than children with DS (60\%). Children with DS preferred walking and gymnastics, while children without DS preferred 
Table 4. Comparison of the results of $1^{\text {st }}$ and $2^{\text {nd }}$ study of physical activity of children without Down syndrome broken down into physical activity of varying intensity. Validation phase (h/day)

\begin{tabular}{|c|c|c|c|c|}
\hline Intensity of physical activity & $\begin{array}{c}1^{\text {st }} \text { study } \\
x \pm S D \\
{[\text { h/day }]}\end{array}$ & $\begin{array}{c}2^{\text {nd }} \text { study } \\
x \pm S D \\
{[\text { h/day }]}\end{array}$ & $\begin{array}{c}\text { Pearson's } \chi^{2} \\
\text { test's level } \\
\text { of significance }\end{array}$ & $\begin{array}{l}\text { Kappa (к) } \\
\text { coefficient }\end{array}$ \\
\hline Moderate-to-vigorous physical activity (MVPA) & $1.33 \pm 1.34$ & $1.35 \pm 1.34$ & NS & $0.95^{\star}$ \\
\hline Light physical activity (LPA) & $1.77 \pm 1.13$ & $1.74 \pm 1.17$ & NS & $0.91^{\star}$ \\
\hline Sitting time & $6.18 \pm 3.76$ & $6.04 \pm 3.79$ & NS & $0.89^{*}$ \\
\hline
\end{tabular}

$x \pm S D-$ mean \pm standard deviation, NS - non-significant, ${ }^{*} \kappa$ coefficient's significance level $(p<0.05)$.

Table 5. Comparison of time and form of physical activity during 1 day on weekdays and at the weekend for children with Down syndrome and children without Down syndrome

\begin{tabular}{|c|c|c|c|}
\hline Variables & $\begin{array}{c}\text { Children with Down } \\
\text { syndrome } \\
x \pm \mathrm{SD} \text { [h/day] }\end{array}$ & $\begin{array}{c}\text { Children without } \\
\text { Down syndrome } \\
x \pm S D \text { [h/day] }\end{array}$ & $\begin{array}{l}\text { Pearson's } \chi^{2} \\
\text { test's level } \\
\text { of significance }\end{array}$ \\
\hline \multicolumn{4}{|l|}{ Physical activity on weekdays: } \\
\hline PE classes & $0.27 \pm 0.14$ & $0.40 \pm 0.15$ & $S$ \\
\hline Additional physical activities & $0.88 \pm 1.08$ & $0.93 \pm 1.19$ & NS \\
\hline Going for walks & $0.26 \pm 0.21$ & $0.31 \pm 0.20$ & NS \\
\hline Cycling & $0.04 \pm 0.08$ & $0.06 \pm 0.10$ & NS \\
\hline Team games & $0.04 \pm 0.09$ & $0.09 \pm 0.12$ & $S$ \\
\hline Running & $0.05 \pm 0.09$ & $0.08 \pm 0.13$ & NS \\
\hline Swimming/swimming classes & $0.07 \pm 0.11$ & $0.06 \pm 0.10$ & NS \\
\hline Gymnastics & $0.21 \pm 0.20$ & $0.07 \pm 0.13$ & $S$ \\
\hline Dance & $0.04 \pm 0.08$ & $0.06 \pm 0.13$ & NS \\
\hline Playground & $0.07 \pm 0.11$ & $0.10 \pm 0.15$ & NS \\
\hline Others & $0.09 \pm 0.13$ & $0.09 \pm 0.12$ & NS \\
\hline Housework & $0.28 \pm 0.18$ & $0.29 \pm 0.21$ & NS \\
\hline Movement (on foot) & $1.13 \pm 0.76$ & $1.42 \pm 0.90$ & NS \\
\hline Watching TV & $1.96 \pm 1.22$ & $1.96 \pm 1.14$ & NS \\
\hline Sitting in front of the computer & $1.23 \pm 1.21$ & $1.35 \pm 1.04$ & NS \\
\hline Playing and doing homework in a sitting position & $2.92 \pm 1.56$ & $3.00 \pm 1.51$ & NS \\
\hline \multicolumn{4}{|l|}{ Physical activity at the weekend: } \\
\hline Housework & $0.54 \pm 0.49$ & $0.69 \pm 0.37$ & NS \\
\hline Movement (on foot) & $1.21 \pm 0.99$ & $1.25 \pm 0.78$ & NS \\
\hline Watching TV & $1.83 \pm 1.06$ & $2.09 \pm 1.51$ & NS \\
\hline Sitting in front of the computer & $1.06 \pm 1.08$ & $1.31 \pm 1.22$ & NS \\
\hline Playing and doing homework in a sitting position & $2.42 \pm 1.29$ & $2.44 \pm 1.20$ & NS \\
\hline
\end{tabular}

$x \pm S D-$ mean \pm standard deviation, $S-$ significant, $N S-$ non-significant.

Table 6. Comparison of times of physical activity of varying intensity during 1 day a week for children with Down syndrome and children without Down syndrome

\begin{tabular}{|lccc|}
\hline Intensity of physical activity & $\begin{array}{c}\text { Children with Down } \\
\text { syndrome } \mathbf{x} \pm \text { SD } \\
{[\text { h/day] }}\end{array}$ & $\begin{array}{c}\text { Children without Down } \\
\text { syndrome } \mathbf{x} \pm \text { SD } \\
{[\mathrm{h} / \text { day] }}\end{array}$ & $\begin{array}{c}\text { Pearson's } \chi^{2} \\
\text { test's level of } \\
\text { significance }\end{array}$ \\
Moderate-to-vigorous physical activity (MVPA) & $1.15 \pm 1.22$ & $1.33 \pm 1.34$ & NS \\
Light physical activity (LPA) & $1.50 \pm 1.10$ & $1.77 \pm 1.13$ & NS \\
Sitting time & $5.88 \pm 3.83$ & $6.18 \pm 3.76$ & NS \\
\hline
\end{tabular}

$x \pm S D-$ mean \pm standard deviation, NS - non-significant. 
walking, playground and team games. Children with DS and without DS spent about $6 \mathrm{~h}$ a day in a sitting position (not including time spent at school). The average time spent on watching TV and using the computer in both children with and without DS significantly exceeded the recommended $2 \mathrm{~h}$ a day. Only $13 \%$ of children with DS and $15 \%$ of children without DS met the above recommendations and used these devices for a shorter period of time. Kaczor-Szkodny et al. also observed a high level of physical activity among the children they studied. Up to $76.8 \%$ of children spent more than 60 minutes a day on additional physical activities other than physical education classes. Almost $45 \%$ of respondents declared that for additional physical activities they spend $2-3 \mathrm{~h}$ or more than $3 \mathrm{~h}$ per day. Children most often chose cycling, team games and walking. In addition, it was observed that up to $56 \%$ of children spent more than $2 \mathrm{~h}$ a day in front of the computer [3]. Other authors in their studies of children and adolescents also observed the disturbing fact of children spending a significant amount of time in a sitting position $[1,18]$.

In studies involving accelerometers, other authors found that the physical activity of most children with DS studied did not exceed 60 min a day. In addition, it has been shown that the level of physical activity decreases with age. Therefore, older groups were less active [19-21]. The results of the study conducted by Esposito et al. showed that children with DS, at the age of 8-16, spent most of the time during the day sitting, and the least time on moderate or intense physical activity. In the above study, a general trend of decreasing physical activity with age was noted, and its lowest level was found at the age of 14-15 [19]. A similar decrease in activity in the oldest age groups was observed in the study of adolescents with DS at the age of 11-20. There were also no significant differences in sitting time and physical activity between weekdays and weekends, or between time spent in school and free time after school [20]. The results of various studies on physical activity of children without DS also indicate that the majority of respondents did not meet the recommendations for spending a minimum of $60 \mathrm{~min}$ a day on physical activity. Similarly to children with DS, it was observed that the level of physical activity is differentiated by age and older children show a lower level of physical activity [22].

Accelerometers appear to be reliable in examining the physical activity of children and adolescents, especially those with developmental and intellectual disabilities [23]. Due to the high cost, this type of research is not always possible. Conducting surveys does not require complicated and expensive equipment and such tests are not burdensome for the participants. The high usefulness of various types of questionnaires for testing children's physical activity has also been confirmed by other authors [3, 18, 24].
The reliability of subjective methods can be improved by involving not only parents in the survey, but also teachers and caretakers who participate in the daily activities of both children with DS and children without genetic defects.

A review of various methods of assessing physical activity indicates that data from questionnaires may differ from those collected using motion sensors [25, 26]. Subjective methods for assessing physical activity are not as accurate as objective ones using motion sensors. The differences in the results obtained from surveys and studies using motion sensors may be due to the overestimation of physical activity by parents in surveys and the indication of a longer time of a given physical activity than is actually the case.

\section{Conclusions}

High repeatability of results obtained by means of a questionnaire used to assess the level of physical activity of children aged 5-14 was found. The developed questionnaire can be a source of reliable information about physical activity of children at this age and can be considered an accurate measurement tool that can be used to study the level of physical activity of both children with DS and children without genetic disorders. It can be used to supplement information obtained in research using objective methods.

Assessment of physical activity of children with DS against their peers without DS showed that both groups were relatively physically active, but most of them exceeded the recommendations for limiting the time spent in a sitting position. The time and intensity of physical activity in both groups were similar. However, recommendations for the duration of moderate and intensive physical activity were met by significantly more children without DS than children with DS (76\% vs. 60\%). Significant differences were also noted regarding the time allocated to individual forms of physical activity: children with DS spent more time on gymnastics, while the time of participating in physical education classes and team games of children with DS was shorter than in children without DS.

\section{Acknowledgments}

The project is supported under the program of the Minister of Science and Higher Education under the name "Regionel Initiative of Excellence" in 20192022, project number: 024/RID/2018/19, financing amount: PLN 11999 000.00.

\section{Conflict of interest}

The authors declare no conflict of interest. 


\section{References}

1. Świderska-Kopacz J, Marcinkowski JT, Jankowska K. Zachowania zdrowotne młodzieży gimnazjalnej i ich wybrane uwarunkowania. Część V. Aktywność fizyczna. Probl Hig Epidemiol 2008; 89: 246-250.

2. Saunders TJ, Gray CE, Poitras VJ, Chaput JP, Janssen I, Katzmarzyk PT, Olds T, Connor Gorber S, Kho ME, Sampson M, Tremblay MS, Carson V. Combinations of physical activity, sedentary behaviour and sleep: relationships with health indicators in school-aged children and youth. Appl Physiol Nutr Metab 2016; 41: 283-293.

3. Kaczor-Szkodny P, Horoch CA, Kulik TB, Pacian A, Kawiak-Jawor E, Kaczoruk M. Aktywność fizyczna i formy spędzania czasu wolnego wśród uczniów w wieku 12-15 lat. Med Og Nauk Zdr 2016; 22: 113-119.

4. Bodys-Cupak I, Grochowska A, Prochowska M. Aktywność fizyczna gimnazjalistów a wybrane wyznaczniki ich stanu zdrowia. Probl Hig Epidemiol 2012; 93: 752-758.

5. Jarosz M. Piramida zdrowego żywienia i stylu życia dla dzieci i młodzieży. Instytut Żywności i Żywienia, Warszawa $2019 ; 1-12$.

6. Zembura P, Korcz A, Cieśla E, Gołdys A, Nałęcz H. Results from Poland's 2018 report card on physical activity for children and youth. J Phys Act Health 2018; 15: 395-397.

7. Garwol K, Herbert J. Wpływ korzystania z technologii cyfrowych na aktywność fizyczną dzieci w wieku 7-17 lat w opinii rodziców. Edukacja Technika Informatyka 2018; 9: 182-187.

8. Bertapelli F, Pitetti K, Agiovlasitis S, Guerra-Juniorb G. Overweight and obesity in children and adolescents with Down syndrome - prevalence, determinants, consequences, and interventions: a literature review. Res Dev Disabil 2016; 57: 181-192.

9. Basil JS, Santoro SL, Martin LJ, Wusik Healy K, Chini BA, Saal HM. Retrospective study of obesity in children with Down syndrome. J Pediatr 2016; 173: 143-148.

10. Adelekan T, Magge S, Shults J. Lipid profiles of children with Down syndrome compared with their siblings. Pediatrics 2012; 129: 1382-1387.

11. Collins K, Staples K. The role of physical activity in improving physical fitness in children with intellectual and developmental disabilities. Res Dev Disabil 2017; 69: 49-60.

12. Pitetti K, Baynard T, Agiovlasitis S. Children and adolescents with Down syndrome: physical fitness and physical activity. J Sport Health Sci 2013; 2: 47-57.

13. Lipert A, Jegier A. Metody pomiaru aktywności ruchowej. Med Sport 2009; 25: 155-68.

14. Wong SL, Leatherdale ST, Manske SR. Reliability and validity of a school-based physical activity questionnaire. Med Sci Sports Exerc 2006; 38: 1593-1600.

15. McMinn AM, van Sluijs EM, Harvey NC, Cooper C, Inskip HM, Godfrey KM, Griffin SJ. Validation of a maternal questionnaire on correlates of physical activity in preschool children. Int J Behav Nutr Phys Act 2009; 6: 81.

16. Philippaerts RM, Matton L, Wijndaele K, Balduck AL, De Bourdeaudhuij I, Lefevre J. Validity of a Physical Activity Computer Questionnaire in 12- to 18-year-old boys and girls. Int J Sports Med 2006; 27: 131-136.

17. Booth ML, Okely AD, Chey T, Bauman A. The reliability and validity of the Adolescent Physical Activity Recall Questionnaire. Med Sci Sports Exerc 2002; 34: 19861995.
18. Mazur J. Aktywność fizyczna młodzieży szkolnej w wieku 9-17 lat - aktualne wskaźniki, tendencje ich zmian oraz wybrane zewnętrzne i wewnętrzne uwarunkowania. Projekt realizowany na zlecenie ministerstwa sportu i turystyki. Raport końcowy. Instytut Matki i Dziecka, Warsaw 2013.

19. Esposito PE, MacDonald M, Hornyak JE, Ulrich DA. Physical activity patterns of youth with Down syndrome. Intellect Dev Disabil 2012; 50: 109-119.

20. Izquierdo-Gomez R, Martínez-Gómez D, Acha A, Veiga OL, Villagra A, Diaz-Cueto M, UP\&DOWN study group. Objective assessment of sedentary time and physical activity throughout the week in adolescents with Down syndrome. The UP\&DOWN study. Res Dev Disabil 2014; 35: 482-489.

21. Ulrich DA, Burghardt AR, Lloyd M, Tiernan C, Hornyak JE. Physical activity benefits of learning to ride a two-wheel bicycle for children with Down syndrome: a randomized trial. Phys Ther 2011; 91: 1463-1477.

22. Baran J. Wpływ aktywności fizycznej i wybranych okołoporodowych czynników ryzyka na występowanie nadwagi i otyłości u dzieci. Dysertacja doktorska. Uniwersytet Rzeszowski 2018.

23. Troiano RP, Berrigan D, Dodd KW, Masse LC, Tilert T, McDowell M. Physical activity in the united states measured by accelerometer. Med Sci Sports Exerc 2008; 40: 181-188.

24. Kubusiak-Słonina A, Grzegorczyk J, Mazur A. Ocena sprawności i aktywności fizycznej dzieci szkolnych z nadmierną i prawidłową masą ciała. Endokrynol Otył Zab Przem Mat 2012; 8: 16-23.

25. Prochaska JJ, Sallis JF, Long B. A physical activity screening measure for use with adolescents in primary care. Arch Pediatr Adolesc Med 2001; 155: 554-559.

26. Biernat E, Stupnicki R. Przegląd międzynarodowych kwestionariuszy stosowanych $\mathrm{w}$ badaniu aktywności fizycznej. Phys Educ Sport 2005; 49: 32-42.

\section{Address for correspondence:}

\section{Anna Wrzochal}

Collegium Medicum

Jan Kochanowski University

al. IX Wieków Kielc 19, 25-317 Kielce, Poland

Phone: +48 725635547

E-mail: annawrzochal.dietetyk@gmail.com 